\title{
INVENTING EXOTICISM
}




\title{
MATERIAL TEXTS
}

\author{
SERIES EDITORS \\ Roger Chartier Leah Price \\ Joseph Farrell Peter Stallybrass \\ Anthony Grafton Michael F. Suarez, S.J.
}

A complete list of books in the series is available from the publisher. 

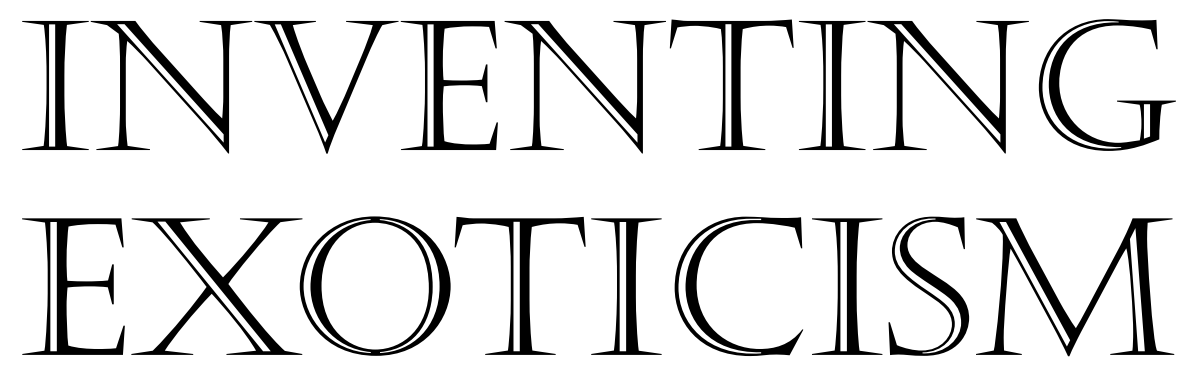

\author{
Geography, Globalism, and \\ Europe's Early Modern World
}

\title{
BENJAMIN SCHMIDT
}

\section{$\overline{\text { PENN }}$}

University of Pennsylvania Press

Philadelphia 
Copyright $\left({ }^{\circ} 2015\right.$ University of Pennsylvania Press

All rights reserved. Except for brief quotations used for purposes of review or scholarly citation, none of this book may be reproduced in any form by any means without written permission from the publisher.

\section{Published by}

University of Pennsylvania Press

Philadelphia, Pennsylvania 19104-4II2 www.upenn.edu/pennpress

Printed in the United States of America on acid-free paper IO 987665432 I

Library of Congress Cataloging-in-Publication Data

Schmidt, Benjamin.

Inventing exoticism : geography, globalism, and Europe's early modern world / Benjamin Schmidt. — Ist ed.

p.cm. - (Material texts)

ISBN 978-0-8122-4646-9 (hardcover : alk. paper)

I. Europe-Civilization-Foreign influences. 2. Geography-

Europe-History-17th century. 3. Geography-Europe-

History-I8th century. 4. Exoticism in art-Europe. 5. Exoticism in

literature. 6. Europe-Civilization-History-17th century. 7. Europe-

Civilization-History-18th century. 8. Netherlands-Civilization-

History-17th century. 9. Netherlands-Civilization-History-18th

century. I. Title. II. Series: Material texts.

$\mathrm{CB}_{203 . S 3372015}$

$940.2^{\prime}{ }^{\prime} 2-\mathrm{dc} 23$

2014030162 
Finally, to them both, with boundless gratitude-

Louise and Isabel 
This page intentionally left blank 